AJChE 2020, Vol. 20, No. 2, 130 - 139

\title{
Study on the Removal of Odorous Gases from Composting Process using Local Bio-Media of Vietnam
}

\author{
Nguyen Nhat Huy ${ }^{*}, 1,2$ \\ Nguyen Thi Thuy ${ }^{2,3}$ \\ Lam Pham Thanh Hien 1,2 \\ Nguyen Thi Thanh Hang ${ }^{1,2}$ \\ Vuong Bao Khuong 1,2 \\ Le Thi Kim Phung 2,4 \\ Nguyen Thi Le Lien ${ }^{*}, 2,4$ \\ 1 Faculty of Environment and Natural Resources, Ho Chi Minh City University of Technology \\ (HCMUT), 268 Ly Thuong Kiet St., Dist. 10, Ho Chi Minh City, Vietnam \\ 2 Vietnam National University Ho Chi Minh City, Linh Trung Ward, Thu Duc District, Ho Chi Minh \\ City, Vietnam \\ ${ }^{3}$ Department of Environmental Engineering, International University, Quarter 6, Linh Trung Ward, \\ Thu Duc District, Ho Ci Minh City, Vietnam \\ ${ }^{4}$ Faculty of Chemical Engineering, Ho Chi Minh City University of Technology (HCMUT), 268 Ly \\ Thuong Kiet St., Dist. 10, Ho Chi Minh City, Vietnam \\ *e-mail: nnhuy@hcmut.edu.vn,ntllien@hcmut.edu.vn
}

Odor pollution is an increasing problem in Vietnam as a tropical country during the urbanization and industrialization. The odor from sewage systems, farms of poultry, pig, and beef, food processing companies, composting factory, and landfills is a severe problem in many nearby residential areas. In this study, two lab-scale biofiltration systems where pristine local bio-media and cultured bio-media with specially formulated microorganisms were employed in biofilters and bio-trickling filter for controls of odor (i.e., hydrogen sulfide and ammonia) from composting process were fabricated and operated. The odorous gas flow was created by composting solid waste collected from an agricultural market (i.e., mainly vegetable), containing low concentrations of $1.32 \pm$ $0.32 \mathrm{mgNH}_{3} \mathrm{~m}^{-3}$ and $5.20 \pm 0.28 \mathrm{mgH}_{2} \mathrm{~S} \mathrm{~m}^{-3}$ under stable condition. For the biofilter model, commercial compost and cow manure were used as substrates and packed into the models. For the bio-trickling filter model, K3 bio-media with biofilm developed by contacting activated sludge was used as packing material. The results showed that adding specially formulated microorganisms could reduce adaption time and lead to slightly better odor control performance. Among the substrates, cow manure provided the highest odorous gas removal efficiency of $\geq 90 \%$ during the stable phase with the elimination capacity of $0.0492 \mathrm{gNH}_{3} \mathrm{~m}^{-3} \mathrm{~h}^{-1}$ and $0.225 \mathrm{gH}_{2} \mathrm{~S} \mathrm{~m}^{-3} \mathrm{~h}^{-1}$. The study results show a high potential of cow manure biofilter for control of $\mathrm{H}_{2} \mathrm{~S}$ and $\mathrm{NH}_{3}$ gases in the practical application under Vietnam's condition.

Keywords: Ammonia, Bio-trickling filter, Biofilter, Compost, Cow manure, Hydrogen sulfide 


\section{INTRODUCTION}

Among air pollution issues, odor pollution is one of the most complicated problems due to the physical, chemical, and biological characteristics of odorous compounds (Conti et al. 2020). The odor is emitted from all human living activities and production at different levels (Conti et al. 2020, Rincón et al. 2019). Although present in low concentration and are met both emission standards and air ambient standards, odorous gases have many negative impacts on people because of their difficulty in treatment and management (Jiang et al. 2017). Among several approaches for odor control and technologies for odor treatment (Conti et al. 2020, Flagan \& Seinfeld, 2012, Ren et al. 2019, Vallero, 2014, Wang et al. 2007), biofiltration is widely recognized as the most environmental-friendly technology due to the employment of microorganisms for odorous compounds uptake and decomposition (Alinezhad et al. 2019, Ying et al. 2020). Biofiltration systems are usually efficiently and economically for removal of air pollutants with low concentrations due to their low capital and operational cost, little maintenance requirements, without the use of toxic chemicals, and working at ambient temperatures and pressures (Burgess et al. 2001, Mudliar et al. 2010, Schlegelmilch et al. 2005).

There are four types of biofiltration models, consisting of biofilter (BF), biotrickling filter (BTF), bio-scrubber (BS), and membrane bio-reactor (MBR) (Barbusinski et al. 2017, Mudliar et al. 2010), which were intensively studied and applied for air pollution control and particularly for odor control (Burgess et al. 2001, Delhoménie \& Heitz, 2005, Groenestijn \& Kraakman, 2005, Guieysse et al. 2008, Hou et al. 2016, Iranpour et al. 2005, Kumar et al. 2008, Mudliar et al. 2010, Muñoz et al. 2010, Muñoz et al. 2007, Schlegelmilch et al. 2005). The biofilter is the oldest technology applied in Europe for odor control from animal farms even before the fundamental science developed to explain the treatment mechanism (Delhoménie \& Heitz, 2005). This technology has been proven to effectively remove around 60 out of 189 HAPs (hazardous air pollutants). It has been applied by 600 industries of a chemical process in Europe (Mudliar et al. 2010) due to its economic effectiveness, low capital and operational costs, low-pressure drop, and without secondary waste.

In biofiltration, bio-media is considered as the "heart" of the treatment system (Mudliar et al. 2010). The requirement of the bio-media for biofilter includes the high specific surface area (for microorganism and gas contact), high porosity (for lowpressure drop), good water retaining (for humidity stabilization), available and sufficient nutrients (for microorganism development), and available and abundant local microorganisms (for adsorption and decomposition of pollutants). It is necessary to look for suitable and available material for biofilter applications under the humid and hot conditions of Vietnam. On that basis, natural materials such as soil, peat, compost, and wood chips have usually been employed as bio-media in biofilter (Mudliar et al. 2010, Pu et al. 2018). Among them, compost has been widely 
used due to its containing abundant and diverse local microorganisms as well as nutrients and humidity (Hou et al. 2016). However, compost has a disadvantage of unstable pellet structure, which is easily corrupted under water's high content.

Cow manure is one of the most popular wastes in rural areas with the development of livestock farming in Vietnam. Once properly collected and treated, cow manure could be a valuable fertilizer with high humus content, stable and porous structure, with available nutrients and active microorganisms. Cow manure was used as bio-media for gas treatment in a study of Zicari (2003), where it was effective for removing $\mathrm{H}_{2} \mathrm{~S}$ gas. Therefore, the application of local cow manure as biomedia for biofilter is the potential to remove odorous gas under Vietnam's condition.

In this study, three models for the biological removal of odorous gases generated from the composting process were fabricated and tested. The systems included a biofilter using cow manure, a biofilter using compost, and a bio-trickling filter using K3 media with biofilm formed by contacting activated sludge. The removal efficiency (\%) and elimination capacity ( $\mathrm{g}$ $\mathrm{m}^{-3} \mathrm{~h}^{-1}$ ) of $\mathrm{H}_{2} \mathrm{~S}$ and $\mathrm{NH}_{3}$ were used to evaluate the performance of the treatment models. The adding of commercial microorganisms dedicated to odor control was also studied for the three models and compared with the locally available ones.

\section{MATERIALS AND METHODS}

The experimental setups for odorous gas removal are illustrated in Figure 1, including a biofilter with cow manure, a biofilter with compost, and a bio-trickling filter with K3 bio-media. The design parameters of the three models are displayed in Table 2.

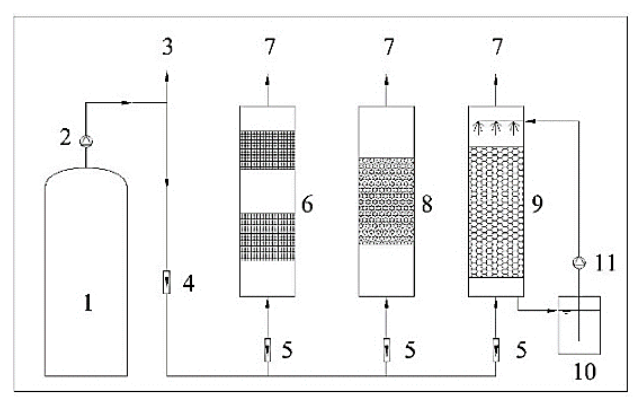

Fig. 1: Experimental setup for odor removal using local bio-media: (1) garbage composting vessel, (2) air pump, (3) inlet sampling point, $(4,5)$ flowmeters, (6) biofilter with cow manure, (7) outlet sampling points, (8) biofilter with compost, (9) bio-trickling filter, (10) wastewater tank, (11) wastewater recirculation pump.

Table 1. Parameter for biofiltration models

\begin{tabular}{|c|c|c|c|c|}
\hline Parameter & Unit & $\begin{array}{l}\text { Biofilter } \\
\text { with cow } \\
\text { manure }\end{array}$ & $\begin{array}{l}\text { Biofilter } \\
\text { with } \\
\text { compost }\end{array}$ & $\begin{array}{c}\text { Bio- } \\
\text { trickling } \\
\text { filter }\end{array}$ \\
\hline $\begin{array}{l}\text { Length } x \\
\text { Width } x \\
\text { Height }\end{array}$ & $\mathrm{mm}$ & $\begin{array}{c}110 \times \\
110 \times \\
1000\end{array}$ & $\begin{array}{c}150 \times \\
150 \times \\
540\end{array}$ & $\begin{array}{l}140 \times \\
140 \times \\
1100\end{array}$ \\
\hline $\begin{array}{l}\text { Bio-media } \\
\text { height }\end{array}$ & $\mathrm{mm}$ & 270 & 170 & 400 \\
\hline $\begin{array}{l}\text { Bio-media } \\
\text { volume }\end{array}$ & L & 3.3 & 3.8 & 7.8 \\
\hline $\begin{array}{c}\text { Bio-media } \\
\text { weight }\end{array}$ & $\mathrm{g}$ & 630 & 2578 & 1256 \\
\hline
\end{tabular}

In these models, the gas flow rate was in a range of $1-4 \mathrm{~L} \mathrm{~min}^{-1}$. Only the BTF model was operated with a liquid flow rate of $0.24 \mathrm{~L} \mathrm{~min}^{-1}$. The design of these models (all were made of acrylic resin) was adopted from the literature for $\mathrm{H}_{2} \mathrm{~S}$ removal in the air (Jin et al. 2005, Zicari, 2003). Another parallel system (the same as the system in Figure 1 and Table 2 and used the same 
inlet gas from the garbage composting process) was set up with the adding of a highly active liquid culture consortium for comparison.

Garbage consisted of vegetable waste collected from Thu Duc Agriculture Market (Ho Chi Minh City, Vietnam) twice a week and kept in a refrigerator. A certain amount of garbage was added into the garbage composting $200 \mathrm{~L}$ vessel every day to maintain the stable inlet odorous gas flow rate and concentration of $\mathrm{H}_{2} \mathrm{~S}$ and $\mathrm{NH}_{3}$. Treated cow manure ("Mien Tay"-Vietnam) was bought from a regular market in $\mathrm{Ho}$ Chi Minh City. It was made from fresh cow dung, which was then composted for around 2 months and dried under sunlight for several days before packaging. Compost was the commercial one (Agrimatin $^{\mathrm{TM}}$ Super Organic, Vietnam) purchased from a regular market in $\mathrm{Ho}$ Chi Minh City. This compost's composition is $72 \%$ organic, $3.5 \% \mathrm{~N}, 2.5 \% \mathrm{P}_{2} \mathrm{O}_{5}$, and $2.5 \%$ $\mathrm{K}_{2} \mathrm{O}$. During the operation, both compost and cow manure bio-media moisture were tested daily and added with water to maintain the moisture at least $50 \%$. The $\mathrm{K} 3$ media was made of HDPE by Kaldness, and the development of biofilm on K3 media was done by culturing this material in an activated sludge tank under continuous aeration. Wastewater in the tank was maintained COD concentration at around $500 \mathrm{mg} \mathrm{L}^{-1}$ for biofilm formation. Ammonia and sulfide were also added to the wastewater for the development of nitrogen and sulfur removal microorganisms. The K3 bio-media (i.e., K3 media with biofilm) was then taken out of the aeration tank and placed in the biotrickling filter and irrigated with recirculated wastewater (without adding ammonia and sulfide) for microorganism growth in the gas phase.

A highly active liquid culture consortium (Microbe-Lift OC-IND, provided by Dat Hop Company, Vietnam) was added with cow manure, compost, and bio-media in the parallel models. This product is specially formulated for organic odor control from animal farms, wastewater treatment plants, and solid wastes collection and treatment in Vietnam. This product's dosage followed the company's suggestion with a volume mixing ratio of $1 / 10$ for cow manure and compost in biofilter and $1 / 100$ for bio-media in the biotrickling filter. In this study, the system without adding Microbe-Lift OC-IND are denoted as local systems, while the ones with Microbe-Lift OC-IND are denoted as cultured systems.

The inlet and outlet gas samples were collected by absorption and analyzed using the Methylene Blue method (for $\mathrm{H}_{2} \mathrm{~S}$ ) and the Indophenol method (for $\mathrm{NH}_{3}$ ). Based on the inlet and outlet concentrations and parameters of the model, the removal efficiency $(H)$ and the elimination capacity (E) were calculated for each model, as follows:

$$
\begin{aligned}
& H=\frac{C_{\text {in }}-C_{\text {out }}}{C_{\text {in }}} \times 100 \% \\
& E=\frac{\left(C_{\text {in }}-C_{\text {out }}\right)}{V} \times Q
\end{aligned}
$$

$H$ is the removal efficiency (\%) and $E$ is the elimination capacity $\left(\mathrm{gNH}_{3} \mathrm{~m}^{-3} \mathrm{~h}^{-1}\right.$ or $\mathrm{gH}_{2} \mathrm{~S}$ $\left.\mathrm{m}^{-3} \mathrm{~h}^{-1}\right) . \mathrm{C}_{\text {in }}$ and $\mathrm{C}_{\text {out }}$ are the inlet and outlet concentrations $\left(\mathrm{mg} \mathrm{m}^{-3}\right)$, respectively. $Q$ is gas flowrate $\left(\mathrm{m}^{3} \mathrm{~h}^{-1}\right)$ and $\mathrm{V}$ is the bio-media volume (L).

\section{RESULTS AND DISCUSSION}


Assessment of $\mathrm{NH}_{3}$ removal efficiency of the different models and microorganism system

The $\mathrm{NH}_{3}$ removal efficiency of the two biofilters and one bio-trickling filter were investigated in the local (i.e., pristine) and culture (i.e., with Microbe-Lift) systems and the results are shown in Figure 2. As seen in Fig. 2(a), during the first 15 days of operation, the $\mathrm{NH}_{3}$ removal efficiency of both local (i.e., pristine) and cultured (i.e., with Microbe-Lift) cow manure models were not stable though the highest removal efficiency achieved was $60 \%$. This period was considered as adaptation time for the microorganism. During this stage, the local cow manure has slightly higher ammonia removal efficiency than the cultured cow manure. After 15 days of adaptation, the removal efficiency of both systems increased and was stable at around 95\% (steady stage). During this steady stage, the cultured cow manure was slightly more efficient and stable than the local one for ammonia removal.

The unsteady performance was also observed for biofilters using compost during the adaptation time (Fig. 2(b)). The cultured compost seemed to be more effective than the local one during the adaptation phase of 10 days, with the highest efficiency of $60 \%$. The local compost showed better performance from the $10^{\text {th }}$ to $20^{\text {th }}$ day with a $50-60 \%$ removal efficiency. However, the performance of both systems became stable with a treatment efficiency of around $75 \%$ after 20 days of operation.
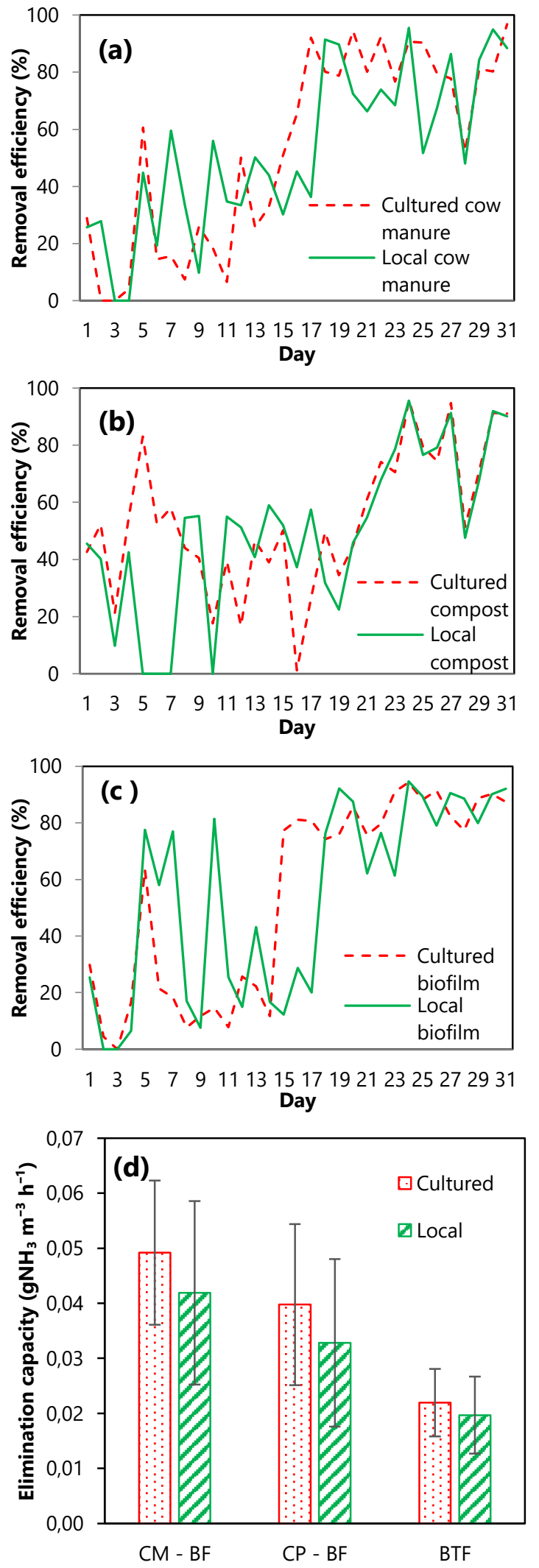

Fig. 2: Ammonia removal efficiency of (a) cow manure biofilter, (b) compost biofilter, (c) bio-trickling filter, and (d) elimination capacity (from day 19) 
In the bio-trickling filter (Fig. 2(c)), the biofilm also needs around 15 days (with cultured microorganism) and 19 days (with local microorganism) for adaptation. During this stage, the removal efficiency varied from 0 to $80 \%$. After reaching a steady stage, both the systems' removal efficiency was similar and efficient at $90 \%$ and above.

The ammonia elimination capacity represents the removal rate, which is depicted in Fig. 2(d) for stable operation days with an inlet concentration of $1.32 \pm$ $0.32 \mathrm{mg} \mathrm{m}^{-3}$. It is clearly observed that the addition of Microbe-Lift enhanced the activity of the bio-media in all systems. Among the three systems, the local cow manure biofilter gave the highest elimination capacity of $0.0492 \mathrm{gNH}_{3} \mathrm{~m}^{-3} \mathrm{~h}^{-1}$ compared to $0.0419 \mathrm{gNH}_{3} \mathrm{~m}^{-3} \mathrm{~h}^{-1}$ in the case of local cow manure one. The lowest elimination capacity was observed in biotrickling filters with $0.0219 \mathrm{gNH}_{3} \mathrm{~m}^{-3} \mathrm{~h}^{-1}$ (cultured system) and $0.0197 \mathrm{gNH}_{3} \mathrm{~m}^{-3} \mathrm{~h}^{-1}$ (local system). These values were very low compared to those reported in the literature because of low inlet concentrations of ammonia generated in the testing models (Martel, 2013, Ramírez et al. 2009). However, since this is a labscale study with an actual condition, the results show the suitability of cow manure adding with Microbe-Lift OC-IND for ammonia removal from the composting process under the condition of Vietnam.

\section{Assessment of $\mathrm{H}_{2} \mathrm{~S}$ removal efficiency of the different models and microorganism system}

The $\mathrm{H}_{2} \mathrm{~S}$ gas generated from vegetable garbage composting is flushed to the different models to examine the removal efficiency and elimination capacity. Figure 3
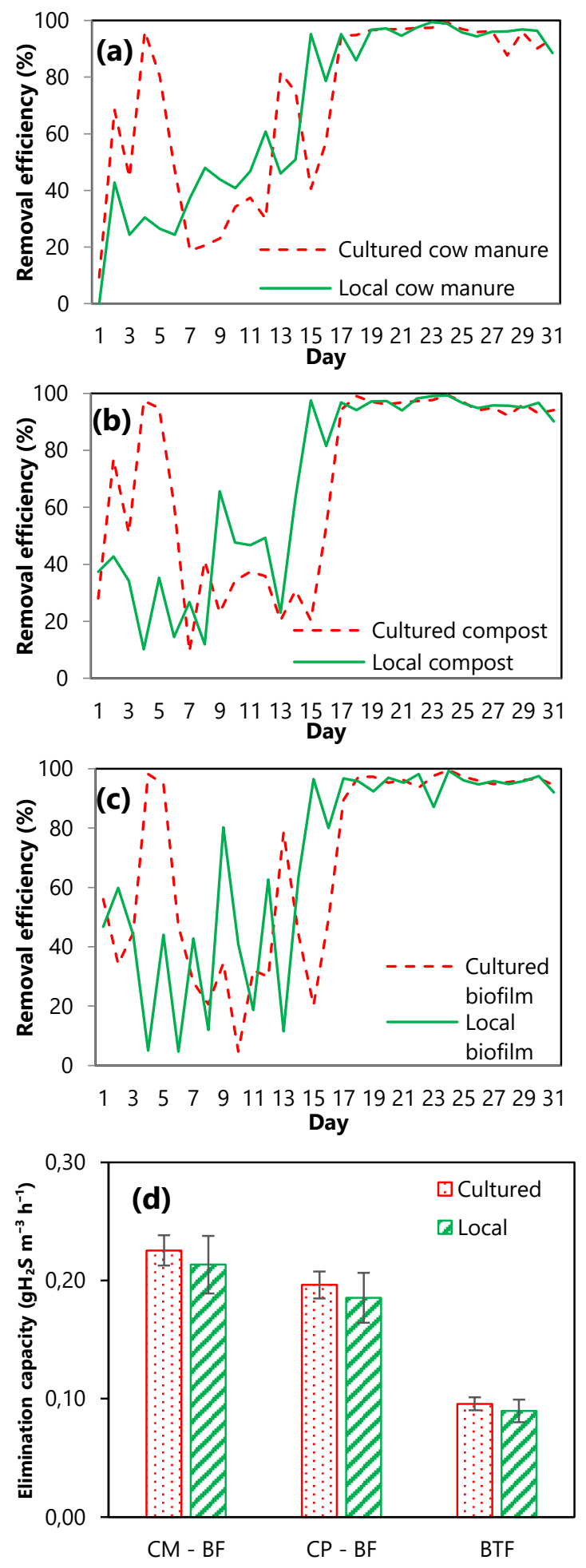

Fig. 3: $\mathrm{H}_{2} \mathrm{~S}$ removal efficiency of (a) cow manure biofilter, (b) compost biofilter, (c) bio-trickling filter, and (d) elimination 
capacity (from day 19)

presents the performance of both local and cultured systems for $\mathrm{H}_{2} \mathrm{~S}$ removal. Generally, the activity of cultured systems was superior to the local ones during the first stage of adaptation, which was around 6 days for all three models. The performance of local systems was then better than that of cultured ones from the $6^{\text {th }}$ to $17^{\text {th }}$ day of the treatment process. Eventually, the performance of both cultured and local systems was similar during the stable phase after around 17 days of the experiment. During this stable phase, the removal efficiency of the three models were $95 \%$ and higher. Compare to ammonia (Fig. 2), the removal of $\mathrm{H}_{2} \mathrm{~S}$ was more stable and higher efficient, showing the higher potential of the studied local microorganism for $\mathrm{H}_{2} \mathrm{~S}$ removal.

The $\mathrm{H}_{2} \mathrm{~S}$ elimination capacity was demonstrated in Fig. 3(d) for stable operation days with an $\mathrm{H}_{2} \mathrm{~S}$ inlet concentration of $5.20 \pm 0.28 \mathrm{mg} \mathrm{m}^{-3}$. The cultured systems also had slightly better elimination capacity than the local ones. Among the three systems, the biofilter with cow manure had the highest elimination capacity of $0.225 \mathrm{gH}_{2} \mathrm{~S} \mathrm{~m}^{-3} \mathrm{~h}^{-1}$ (for the cultured system) and $0.213 \mathrm{~g} \mathrm{H}_{2} \mathrm{~S} \mathrm{~m}^{-3} \mathrm{~h}^{-1}$ (for the local system). The lowest removal rate was observed in the bio-trickling filter with the elimination capacities of 0.096 and $0.090 \mathrm{gH}_{2} \mathrm{~S} \mathrm{~m}^{-3} \mathrm{~h}^{-1}$ for cultured and local systems. These values were very low as compared to the literature (Barbusiński \& Kalemba, 2016, Cox \& Deshusses, 2002, Dumont et al. 2008, Gabriel \& Deshusses, 2003, Jin et al. 2005, Kim et al. 2002, Vikrant et al. 2018, Yang \& Allen, 1994a, 1994b, Zicari, 2003), which could be due to the low inlet concentration of $\mathrm{H}_{2} \mathrm{~S}$ from composting process in this study. However, the results have shown the promising of $\mathrm{H}_{2} \mathrm{~S}$ removal by available cow manure under Vietnam's condition.

Figure 4 depicts the effect of the inlet gas flow rate on all six biological filtration models' performance. Generally, the ammonia removal efficiency decreased with the increase of gas flow rate, whereas the hydrogen sulfide removal remained almost unchanged. Although there was a fluctuation in BTF performance, $\mathrm{NH}_{3}$ removal appeared to be more sensitive than $\mathrm{H}_{2} \mathrm{~S}$ to the change of gas flow rate, which the removal efficiency decreased from around $88 \%$ to around $54 \%$ when flow rate increased from 1 to $4 \mathrm{~L} \mathrm{~min}^{-1}$. On the other hand, the treatment ability of all six systems was not affected by the increase of gas flow rate, indicating that these systems
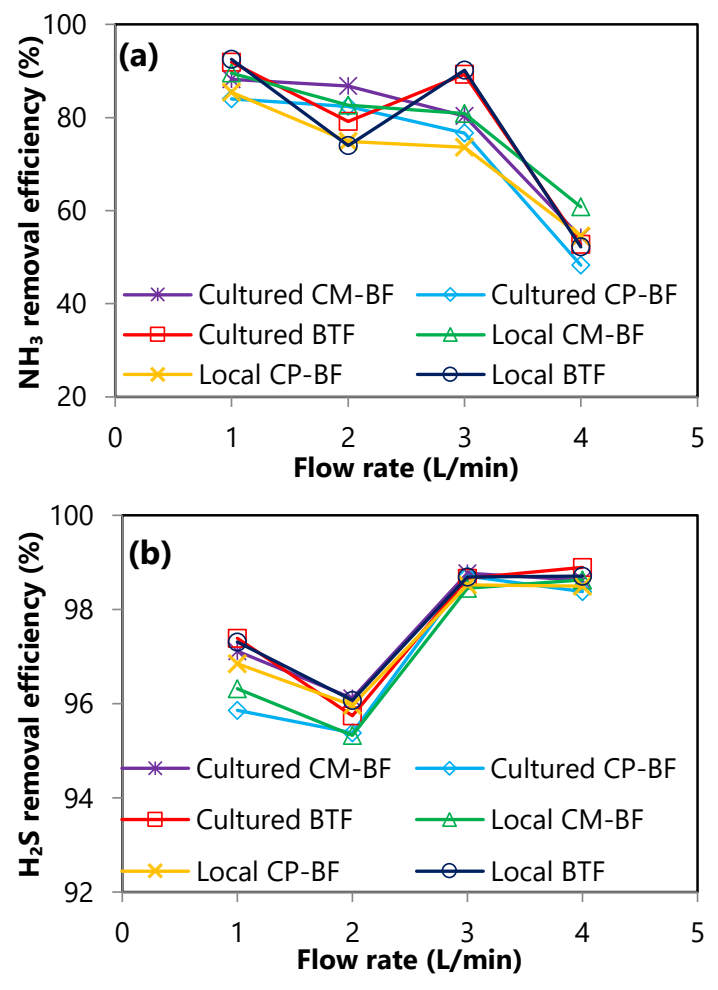

Fig. 4: Effect of inlet gas flow rate on the removal efficiency of all models for (a) 
ammonia and (b) hydrogen sulfide

are more suitable for the removal of $\mathrm{H}_{2} \mathrm{~S}$ gas. It may be because all these systems were set up based on the best practice of biofilter and bio-trickling filter for $\mathrm{H}_{2} \mathrm{~S}$ removal in the literature. It also suggests that the performance for $\mathrm{NH}_{3}$ removal should be improved in the future, and the possible way could be taking into account the characteristics of the microorganism community in the bio-media.

\section{CONCLUSIONS}

Two biofiltration systems of cultured microorganisms and local bio-media were set up and operated for ammonia and hydrogen sulfide removal generated from vegetable garbage composting. Each system included three models, including a biofilter with cow manure, a biofilter with compost, and a bio-trickling filter with $\mathrm{K} 3$ bio-media. The results showed that the cultured system adapted faster and provided a slightly higher elimination ability than the local ones. However, all six models started to operate stably after around 19 days of adaptation with high $\mathrm{NH}_{3}$ and $\mathrm{H}_{2} \mathrm{~S}$ removal efficiency of over $90 \%$ in the experimental conditions. Among the bio-media, the biofiltration model with cow manure was proven to be the most suitable one for application in $\mathrm{NH}_{3}$ and $\mathrm{H}_{2} \mathrm{~S}$ control from the composting process. However, compost biofilter and bio trickling filter also have good treatment ability, especially for low inlet gas concentration. It suggests a great potential for cow manure to be a promising bio-media for control of odor from garbage and compost under
Vietnam's condition.

\section{ACKNOWLEDGEMENT}

This research is funded by Vietnam National University - Ho Chi Minh City under grant number C2018-20-20.

\section{REFERENCES}

1. Alinezhad, E., Haghighi, M., Rahmani, F., Keshizadeh, H., Abdi, M., and Naddafi, K. (2019). "Technical and economic investigation of chemical scrubber and bio-filtration in removal of $\mathrm{H} 2 \mathrm{~S}$ and $\mathrm{NH} 3$ from wastewater treatment plant," J. Environ. Manage., 241, 32-43.

2. Barbusiński, K., and Kalemba, J. (2016). "Use of biological methods for removal of $\mathrm{H}_{2} \mathrm{~S}$ from biogas in wastewater treatment plants-a review," Architecture Civil Engineering Environment, 9(1), 103-112.

3. Barbusinski, K., Kalemba, K., Kasperczyk, D., Urbaniec, K., and Kozik, V. (2017). "Biological methods for odor treatment - A review," J. Cleaner Prod., 152, 223241.

4. Burgess, J. E., Parsons, S. A., and Stuetz, R. M. (2001). "Developments in odour control and waste gas treatment biotechnology: a review," Biotechnol. Adv., 19(1), 35-63.

5. Conti, C., Guarino, M., and Bacenetti, J. (2020). "Measurements techniques and models to assess odor annoyance: A review," Environ. Int., 134, 105261.

6. Cox, H. H. J., and Deshusses, M. A. (2002). "Co-treatment of $\mathrm{H}_{2} \mathrm{~S}$ and toluene in a biotrickling filter," Chem. Eng. J., 87(1), 101-110. 
7. Delhoménie, M.-C., and Heitz, M. (2005). "Biofiltration of air: a review," Crit. Rev. Biotechnol., 25(1-2), 53-72.

8. Dumont, E., Andrès, Y., Le Cloirec, P., and Gaudin, F. (2008). "Evaluation of a new packing material for $\mathrm{H}_{2} \mathrm{~S}$ removed by biofiltration," Biochem. Eng. J., 42(2), 120-127.

9. Flagan, R. C., and Seinfeld, J. H. (2012). Fundamentals of Air Pollution Engineering, Dover.

10. Gabriel, D., and Deshusses, M. A. (2003). "Performance of a full-scale biotrickling filter treating $\mathrm{H} 2 \mathrm{~S}$ at a gas contact time of 1.6 to 2.2 seconds," Environ. Prog., 22(2), 111-118.

11. Groenestijn, J. W. v., and Kraakman, N. J. R. (2005). "Recent developments in biological waste gas purification in Europe," Chem. Eng. J., 113(2-3), 85-91.

12. Guieysse, B., Hort, C., Platel, V., Munoz, R., Ondarts, M., and Revah, S. (2008). "Biological treatment of indoor air for VOC removal: Potential and challenges," Biotechnol. Adv., 26(5), 398-410.

13. Hou, J., Li, M., Xia, T., Hao, Y., Ding, J., Liu, D., Xi, B., and Liu, H. (2016). "Simultaneous removal of ammonia and hydrogen sulfide gases using biofilter media from the biodehydration stage and curing stage of composting," Environ. Sci. Pollut. Res., 23(20), 2062820636.

14. Iranpour, R., Cox, H. H. J., Deshusses, M. A., and Schroeder, E. D. (2005). "Literature review of air pollution control biofilters and biotrickling filters for odor and volatile organic compound removal," Environ. Prog., 24(3), 254-267.
15. Jiang, G., Melder, D., Keller, J., and Yuan, Z. (2017). "Odor emissions from domestic wastewater: A review," Crit. Rev. Environ. Sci. Technol., 47(17), 1581 1611.

16. Jin, Y., Veiga, M. C., and Kennes, C. (2005). "Autotrophic deodorization of hydrogen sulfide in a biotrickling filter," J. Chem. Technol. Biotechnol., 80(9), 9981004.

17. Kim, H., Kim, Y. J., Chung, J. S., and Xie, Q. (2002). "Long-Term Operation of a Biofilter for Simultaneous Removal of $\mathrm{H}_{2} \mathrm{~S}$ and $\mathrm{NH}_{3}, "$ J. Air Waste Manage. Assoc., 52(12), 1389-1398.

18. Kumar, A., Dewulf, J., and Van Langenhove, H. (2008). "Membranebased biological waste gas treatment," Chem. Eng. J., 136(2-3), 82-91.

19. Martel, M. (2013). Simulation Study on Ammonia Removal in a Biotrickling Filter Using a Steady-state Model. Paper presented at the CSBE/SCGAB 2013 Annual Conference Canada.

20. Mudliar, S., Giri, B., Padoley, K., Satpute, D., Dixit, R., Bhatt, P., Pandey, R., Juwarkar, A., and Vaidya, A. (2010). "Bioreactors for treatment of VOCs and odours - A review," J. Environ. Manage., 91(5), 1039-1054.

21. Muñoz, R., Sivret, E. C., Parcsi, G., Lebrero, R., Wang, X., Suffet, I. H., and Stuetz, R. M. (2010). "Monitoring techniques for odour abatement assessment," Water Res., 44(18), 51295149.

22. Muñoz, R., Villaverde, S., Guieysse, B., and Revah, S. (2007). "Two-phase partitioning bioreactors for treatment of volatile organic compounds," Biotechnol. Adv., 25(4), 410-422. 
23. Pu, S., Liu, Z., Yang, F., Long, D., Liu, W., Wang, H., Huang, K., and Huang, X. (2018). "Comparative study on the removal efficiency of hydrogen sulfide (H2S) using three different packings," J. Air Waste Manage. Assoc., 68(9), 900908.

24. Ramírez, M., Gómez, J. M., Aroca, G., and Cantero, D. (2009). "Removal of ammonia by immobilized Nitrosomonas europaea in a biotrickling filter packed with polyurethane foam," Chemosphere, 74(10), 1385-1390.

25. Ren, B., Zhao, Y., Lyczko, N., and Nzihou, A. (2019). "Current Status and Outlook of Odor Removal Technologies in Wastewater Treatment Plant," Waste Biomass Valorization, 10(6), 1443-1458.

26. Rincón, C. A., De Guardia, A., Couvert, A., Le Roux, S., Soutrel, I., Daumoin, M., and Benoist, J. C. (2019). "Chemical and odor characterization of gas emissions released during composting of solid wastes and digestates," J. Environ. Manage., 233, 39-53.

27. Schlegelmilch, M., Streese, J., and Stegmann, R. (2005). "Odour management and treatment technologies: An overview," Waste Manage., 25(9), 928-939.

28. Vallero, D. (2014). Fundamentals of Air Pollution, Elsevier Science.

29. Vikrant, K., Kailasa, S. K., Tsang, D. C. W., Lee, S. S., Kumar, P., Giri, B. S., Singh, R. S., and Kim, K.-H. (2018). "Biofiltration of hydrogen sulfide: Trends and challenges," J. Cleaner Prod., 187, 131147.

30. Wang, L. K., Pereira, N. C., and Hung, Y. T. (2007). Advanced Air and Noise
Pollution Control, Humana Press.

31. Yang, Y., and Allen, E. R. (1994a). "Biofiltration Control of Hydrogen Sulfide 1. Design and Operational Parameters," Air Waste, 44(7), 863-868.

32. Yang, Y., and Allen, E. R. (1994b). "Biofiltration Control of Hydrogen Sulfide 2. Kinetics, Biofilter Performance, and Maintenance," Air Waste, 44(11), 1315-1321.

33. Ying, S., Kong, X., Cai, Z., Man, Z., Xin, Y., and Liu, D. (2020). "Interactions and microbial variations in a biotrickling filter treating low concentrations of hydrogen sulfide and ammonia," Chemosphere, 255, 126931.

34. Zicari, S. M. (2003). Removal of hydrogen sulfide from biogas using cow-manure compost, Cornell University. 